\title{
Significant Winter Weather Events and Associated Socioeconomic Impacts (Federal Aid Expenditures) across Oklahoma: 2000-10
}

\author{
TREVOR GROUT AND YANG HONG \\ School of Civil Engineering and Environmental Science, and the Atmospheric Radar Research Center, \\ University of Oklahoma, Norman, Oklahoma \\ JEFFREY BASARA \\ Oklahoma Climatological Survey, and School of Meteorology, University of Oklahoma, Norman, Oklahoma
}

BALABHASKAR BALASUndARAM, ZHENYU Kong, AND SATISH T. S. BUKKAPATNAM

School of Industrial Engineering and Management, Oklahoma State University, Stillwater, Oklahoma

(Manuscript received 11 June 2010, in final form 16 September 2011)

\begin{abstract}
Exceptionally severe winter storms that overwhelm local government result in major disaster declarations. Each National Weather Service forecast office in the United States reports winter events for a specific group of counties, known as the county warning area. Such events are reported as blizzard, ice storm, winter storm, heavy snow, or winter weather. They are archived by the National Climatic Data Center and are published in Storm Data, a monthly periodical. Using Storm Data, all winter reports in Oklahoma from 1 November 1999 to 1 May 2010 were compiled into a database. The results of this study demonstrated that while counties in northern Oklahoma received the highest number of winter reports, when compared with climatology winter storm, heavy snow, ice storm, and blizzard storm types yielded an above-average occurrence across much of southwest and central Oklahoma over the study period.

Disaster information, obtained from the Federal Emergency Management Agency, showed that from 1 November 1999 to 1 May 2010 Oklahoma led the nation with nine winter-related federal disasters, resulting in nearly $\$ 800$ million (U.S. dollars) in federal aid. High-impact events, determined by disaster declarations, were most frequent across southwest, central, and northeast Oklahoma, and southwest Oklahoma experienced a disaster nearly every third winter event. Over much of Oklahoma, ice storms were more likely to result in a disaster than winter storm, blizzard, and heavy snow events combined. Spatial distributions of federal aid showed that rural counties were most impacted by the winter weather disasters and required greater federal assistance.
\end{abstract}

\section{Introduction}

While winter weather is a common occurrence throughout many regions of the United States, the impact of significant winter storms (typically classified as snowstorms or ice storms) has yielded an increasing toll on society. For example, more winter storm-related major disaster declarations have been declared over the past decade (1 January 2000-31 December 2010; 122 declarations) than over the previous 47 yr (1 January 1953-31 December 1999; 83 declarations) (FEMA 2011b).

Corresponding author address: Dr. Yang Hong, Atmospheric Radar Research Center, University of Oklahoma, 120 David L. Boren Blvd., Ste. 4610, Norman, OK 73072.

E-mail: yanghong@ou.edu
In terms of overall winter storms, while Changnon (2007) found that from 1949 to 2003 a statistically significant decrease in the number of catastrophic winter storms existed across the United States [i.e., storms with at least \$1 million (U.S. dollars) damage], the results of the study also found that a statistically significant upward trend existed in the intensity of the storms measured by monetary costs. Thus, while the frequency of catastrophic winter storms decreased, the overall events incur a greater impact. This study examines high-impact winter storms that occurred across Oklahoma (located in the southern United States) over a 10-yr period spanning 2000-10 to determine the climatological relevance of the events and economic impacts based on federal aid expenditures. 
When analyzed on a regional scale, Changnon (2007) found that catastrophic winter storms were most frequent in the northeast United States and least frequent in the western United States. Further, despite a decreasing national trend, Oklahoma experienced a $105 \%$ increase in catastrophic storm incidences during the 20 -yr period between 1984 and 2003 when compared to the previous 20-yr period from 1964 to 1983 . Changnon (2007) also found that, over the same periods, average catastrophic storm losses increased by $291 \%$ across the South climate district of the United States (including Oklahoma).

In terms of the regional climatology of snowstorms (defined by accumulations greater than $15.2 \mathrm{~cm}$ in 2 days or less) between 1901 and 2001, snowstorm frequency remained constant across southern Oklahoma throughout the entire period, while in northern Oklahoma the snowstorm frequency decreased over the same period (Changnon et al. 2006). Changnon et al. (2006) also showed that an average of five snowstorms occur every $10 \mathrm{yr}$ in northwest Oklahoma, while one snowstorm occurs every $10 \mathrm{yr}$ in central and southern Oklahoma. The results of the study also noted that over the same 100-yr period, snowstorms were most frequent in Oklahoma during January and February, while Changnon (2006) determined that the 10-yr return period for a snowstorm ranged from more than $20 \mathrm{~cm}$ in northwest Oklahoma to slightly more than $15 \mathrm{~cm}$ in southeast Oklahoma. In a statewide study, Branick (2011) found that although snowfall events in Oklahoma were most numerous in January, March was the most likely time to experience "mega snowstorms" (snowfall totals in excess of $40 \mathrm{~cm}$ ). One such mega snowstorm impacted much of northwest Oklahoma in March 2009 with accumulations of approximately $60 \mathrm{~cm}$.

In addition to heavy snowfall events, dangerous ice storms also occur in Oklahoma. A climatological study of ice storms from 1949 to 2000 by Jones et al. (2002) estimated the 50-yr return period for ice storms over much of Oklahoma is $1.9 \mathrm{~cm}$ or greater of ice accumulation accompanied with $17 \mathrm{~m} \mathrm{~s}^{-1}$ wind speed values. Changnon and Karl (2003) revealed that freezing rain events in the South climate district of the United States (including Oklahoma) were most common in December (northwest Oklahoma) and January (central/southern Oklahoma), and that the number of freezing rain days steadily increased from 1985 to 2000.

While winter storms, particularly ice storms, are most frequent in the northeast United States (Changnon and Karl 2003; Changnon 2007), Changnon (2003) noted that in the southern United States (including Oklahoma) when freezing rain occurred, 1) it was more likely to be catastrophic and 2) the region had the greatest ice accumulations. Rauber et al. (2001) explained that ice storms in the
United States are most frequently caused by Arctic cold fronts moving southward as warm, moist air ascends over the front. Rauber et al. (2001) further explained that this process is pronounced in the southern United States because the air is very warm and moist, and that the Arctic fronts typically slow in speed, or even stall. Such conditions can increase precipitation intensity, lengthen storm duration, and produce devastating ice accumulations.

The economic and social costs from high-impact ice storms are compounded due to 1 ) the infrequent nature of freezing rain events and 2) fewer resources to treat the excessive ice as it accumulates on exposed surfaces, including roads, power lines, and utilities. Call (2010) noted that power outages are the most adverse impact of ice storms because people have no way to heat their homes. In addition, other major impacts of ice storms include transportation disruptions, the shutdown of commercial businesses, and agricultural losses. Changnon (2003) found that in the South climate district of the United States (including Oklahoma), the average cost for catastrophic ice storms, property losses greater than $\$ 1$ million, occurring from 1949 to 2000 was $\$ 78$ million (inflation adjusted cost for the year 2000).

Eight ice storm-related major disaster declarations received for the U.S. Federal Emergency Management Agency (FEMA) region VI (Louisiana, Arkansas, Oklahoma, Texas, and New Mexico) in the southern United States in the period 24 December 1964-1 January 2010 occurred from 10 January 2000 to 1 January 2010 and accounted for more than a quarter of the 29 nationally declared disasters during the same period. Conversely, prior to 2000, the region did not experience a single ice storm event that required major disaster status (FEMA 2011e,f). Yet, in the most recent decade, eight highimpact ice storms overwhelmed the ability of local government such that disaster declarations were required.

The state of Oklahoma has been particularly affected by multiple high-impact winter events from 2000 to 2010, including ice storms, heavy snowfall, and blizzard conditions. At the same time, when compared to other regions of the United States, the climate of Oklahoma is defined by relatively mild winters. Yet, during the study period spanning 1 November 1999 to 1 May 2010, Oklahoma led the nation with nine winter weather-related major disaster declarations (FEMA 2011b). From a scientific and socioeconomic standpoint, it is critical to quantify how extreme weather events impact the human populace. As such, to better understand the consequences of the recent high-impact winter weather events in Oklahoma, this study compiled all U.S. National Weather Service (NWS) winter weather reports for the 10-yr period with specific goals to determine 1) the spatial distribution of winter weather in Oklahoma during the 
TABLE 1. Definition of storm type reports from National Weather Service offices.

\begin{tabular}{|c|c|c|c|c|}
\hline & Amarillo Forecast Office & Norman Forecast Office & Tulsa Forecast Office & Shreveport Forecast Office \\
\hline Blizzard* & \multicolumn{4}{|c|}{$\begin{array}{l}\text { A blizzard means that the following conditions are expected to prevail for a period of } 3 \mathrm{~h} \text { or longer: } \\
\text { - Sustained wind or frequent gusts to } 15 \mathrm{~m} \mathrm{~s}^{-1}\left(35 \mathrm{mi} \mathrm{hr}^{-1}\right) \text { or greater } \\
\text { - Considerable falling and/or blowing snow [i.e., reducing visibility frequently to less than } 0.4 \mathrm{~km}(1 / 4 \mathrm{mi})]\end{array}$} \\
\hline Ice storm* & \multicolumn{4}{|c|}{ Freezing rain accumulations of $0.64 \mathrm{~cm}(1 / 4 \mathrm{in}$.$) or more$} \\
\hline $\begin{array}{l}\text { Winter } \\
\text { storm** }\end{array}$ & $\begin{array}{l}\text { Snow accumulation of } 15 \mathrm{~cm} \\
(6 \text { in.) or more in } 24 \mathrm{~h} \text {, and/or } \\
\text { sleet accumulation of } 5 \mathrm{~cm} \\
\text { ( } 2 \text { in.) or more }\end{array}$ & $\begin{array}{l}\text { Snow accumulation of } \\
10 \mathrm{~cm}(4 \mathrm{in} .) \text { or more in } \\
12 \mathrm{~h} \text {, or } 15 \mathrm{~cm}(6 \mathrm{in} .) \text { or } \\
\text { more in } 24 \mathrm{~h} \text { and/or sleet }\end{array}$ & $\begin{array}{l}\text { Snow accumulation of } \\
10 \mathrm{~cm}(4 \mathrm{in} .) \text { or more, } \\
\text { and/or sleet accumulation } \\
\text { of } 10 \mathrm{~cm}(4 \mathrm{in} .) \text { or more }\end{array}$ & $\begin{array}{l}\text { Snow accumulation of } 10 \mathrm{~cm} \\
\text { ( } 4 \text { in.) or more in } 12 \mathrm{~h} \text { or } \\
\text { between } 10 \text { and } 15 \mathrm{~cm} \\
\text { (4-6 in.) in } 24 \mathrm{~h} \text {, and/or } \\
\text { sleet accumulation of } \\
1.25 \mathrm{~cm}(0.5 \text { in) or more }\end{array}$ \\
\hline $\begin{array}{l}\text { Heavy } \\
\text { snow }^{* * * *}\end{array}$ & $\begin{array}{l}\text { Snow accumulation of } 10 \mathrm{~cm}(4 \mathrm{i} \\
\text { in } 24 \mathrm{~h}\end{array}$ & n.) or more in $12 \mathrm{~h}$, or $15 \mathrm{~cm}$ & (6 in.) or more & $\begin{array}{l}\text { Snow accumulation of } 10 \mathrm{~cm} \\
\text { (4 in.) or more in } 12 \mathrm{~h} \text {, or } \\
\text { between } 10 \text { and } 15 \mathrm{~cm} \\
\text { (4-6 in.) in } 24 \mathrm{~h}\end{array}$ \\
\hline $\begin{array}{l}\text { Winter } \\
\text { weather*** }\end{array}$ & \multicolumn{4}{|c|}{$\begin{array}{l}\text { Issued for winter weather events that are of significance to the public but do not constitute a serious enough } \\
\text { threat to life and property to warrant a warning }\end{array}$} \\
\hline
\end{tabular}

* From NWS (2011a).

** From D. Andra (Norman NWS Office, 2011, personal communication).

study period, 2) whether the events occurred within climatological norms, and 3) the overall socioeconomic impacts, through federal aid expenditures, of the severe, high-impact winter weather events.

\section{Methods}

Data for this study primarily consist of two sources. The first is the Storm Data publication (Storm Data), an official publication of the National Oceanic and Atmospheric Administration available from the National Climate Data Center (NCDC). The Storm Data resource contains a listing of storm occurrences and unusual weather phenomena across the United States (NOAA 2011). The second dataset was obtained from FEMA and was used to identify regions affected by high-impact storms and to determine a baseline for economic impacts from each event.

\section{a. Storm Data}

All offices of the U.S. NWS relay confirmed winter weather reports to the NCDC for their county warning area (CWA), the specific geographic region for which each office is responsible for issuing forecasts, advisories, and alerts. The NCDC then archives and publishes this information in a monthly publication called Storm Data. The NWS classifies winter weather into five different categories: ice storm, blizzard, winter storm, heavy snow, and winter weather (NWS 2011b; Table 1).

All winter events from 1 November 1999 to 1 May 2010 were manually archived from Storm Data. Information such as date, time, counties affected, storm type, and event summaries were recorded from Storm Data. With few exceptions, one storm report corresponded with one storm event (e.g., one ice storm report corresponded with one ice storm event).

\section{b. FEMA datasets}

With the passage of the Open Government directive (Orszag 2009), FEMA posted three datasets: FEMA Disaster Declarations Summary, FEMA Public Assistance Funded Projects Summary, and FEMA Hazard Mitigation Program Summary (FEMA 2011a,c,d). When a federal disaster is declared, states may apply for monetary aid from the federal government to offset costs involved with recovery and prevention (FEMA 2011g). Although the approval for major disaster status is mainly influenced by the severity of the event, there is some debate as to whether political considerations are a factor in the major disaster declaration process. For example, Sylves and Búzás (2007) suggested that federal disaster status may be politically influenced. However, Salkowe and Chakraborty (2009) found that no significant evidence exists that the disaster decision-making process is politically influenced. Thus, while the disaster declaration process may not be completely immune from external geopolitical influences, it is a relevant, critical metric that is publicly available by which to distinguish catastrophic events from those that are not.

Federal aid received from disaster assistance can only be used for public infrastructure repair, such as rural electric cooperatives, roads, bridges, water treatment plants, parks, and debris removal (M. Ooten 2009, personal communication). Although only a fraction of total losses is covered by federal aid, it is a reliable baseline for total storm losses, and associated socioeconomic impact, in a region. The federal aid disbursed in a particular region is a solid 
TABLE 2. Cost summary for major disaster declarations.

\begin{tabular}{|c|c|c|c|c|c|c|}
\hline Disaster & Size ( $\%$ of counties) & Open date & Close date & $\begin{array}{l}\text { Public assistance } \\
2010 \text { amount }(\$)\end{array}$ & $\begin{array}{l}\text { Hazard mitigation } \\
2010 \text { amount }(\$)\end{array}$ & Total cost $(\$)$ \\
\hline 1355 & 84.42 & 25 Dec 2000 & 10 Jan 2001 & 195273585 & 58576438 & 253850023 \\
\hline 1401 & 58.44 & 30 Jan 2002 & 11 Feb 2002 & 131435131 & 46367469 & 177802600 \\
\hline 1452 & 18.18 & 3 Dec 2002 & 4 Dec 2002 & 5142582 & 1484434 & 6627016 \\
\hline 1677 & 3.90 & 28 Dec 2006 & 30 Dec 2006 & 7131386 & 2567485 & 9698871 \\
\hline 1678 & 62.34 & 12 Jan 2007 & 26 Jan 2007 & 82643557 & 21767162 & 104410720 \\
\hline 1735 & 32.47 & 8 Dec 2007 & 3 Jan 2008 & 103873997 & 31782101 & 135656098 \\
\hline 1823 & 12.99 & 26 Jan 2009 & 28 Jan 2009 & 9479711 & 1973631 & 11453341 \\
\hline 1876 & 70.13 & 24 Dec 2009 & 25 Dec 2009 & 18063800 & 979946 & 19043746 \\
\hline \multirow[t]{2}{*}{1883} & 64.94 & 28 Jan 2010 & 30 Jan 2010 & 75457829 & 1587897 & 77045726 \\
\hline & & & Totals & 628501577 & 167086563 & 795588140 \\
\hline
\end{tabular}

indicator of the inability of the local tax base to bear the losses resulting from high-impact events. Using the consumer price index, all losses were adjusted for inflation to 2010 dollars (Table 2).

\section{1) FEMA DisASTER DeClarations SumMARy}

The FEMA Disaster Declarations Summary (Declaration) dataset lists all declared major disasters since 1950. This dataset includes the unique disaster number, dates of declaration, dates of incident, and names of counties affected.

\section{2) FEMA Public Assistance Funded PROJECTS SUMMARY}

The FEMA Public Assistance Funded Projects Summary (PA) dataset lists all of the money disbursed by the federal government due to major disasters. The PA funds offset costs to public property and interests, and do not include funds distributed by private insurance companies. Further, the PA dataset lists how federal aid was disbursed by agency, organization, declaration number, and county.

\section{3) FEMA Hazard Mitigation Program SUMMARY}

The FEMA Hazard Mitigation Program (HM) dataset lists money disbursed by FEMA to pay for projects that will help prevent future damages from occurring. This dataset lists total costs of a project, location of project, and disaster number associated with the project.

There are additional forms of disaster assistance available to U.S. citizens following a disaster declaration, such as individual assistance, which can provide housing assistance to displaced victims, as well as small loans to help cover uninsured losses (FEMA 2011g). Although these additional federal funds are associated with a disaster event, the allocations were not publicly available for this study and were omitted. However, the three publicly available FEMA datasets (Declaration, PA, and HM) were used to analyze spatial patterns of major disasters in Oklahoma, as well as economic impacts on the state. Costs associated with the PA and HM datasets were combined to determine the total public costs associated with the winter weather disasters during this study. Because all of the data sources for this study reported locations by county, the spatial resolution of this study is at the county level. There are several cases where funds, sometimes considerable amounts, disbursed by the federal government were distributed statewide, as opposed to an individual county. These statewide disbursements were omitted from the county analysis but were included when calculating overall total costs.

\section{Results and discussion}

\section{a. Storm data analysis}

The FEMA datasets demonstrated that nine major disasters were declared for Oklahoma due to winter weather-related conditions during the study period (2000-10). In addition, the nine declarations were the greatest number of any state in the United States during the period. The counties with the most disaster declarations were oriented southwest to northeast and include southwest, central, and northeast Oklahoma (Fig. 1).

In terms of individual storm reports, from 2000 to 2010, the highest concentration of total winter reports occurred in north-central Oklahoma and the lowest concentration occurred in extreme southern and southeastern Oklahoma (Fig. 2). Biases in reporting, due to population, were nonexistent as the correlation between total storm reports and population yielded an $R^{2}$ value of 0.01 . For individual storm types (Fig. 3), ice storm reports were primarily concentrated in a southwest-northeast orientation, including much of southwest, central, and northeast Oklahoma. This ice storm pattern was significant because the state's four most populous cities (Oklahoma City, Tulsa, Norman, and Lawton) were located within this region. Heavy snow was most frequently reported in the 


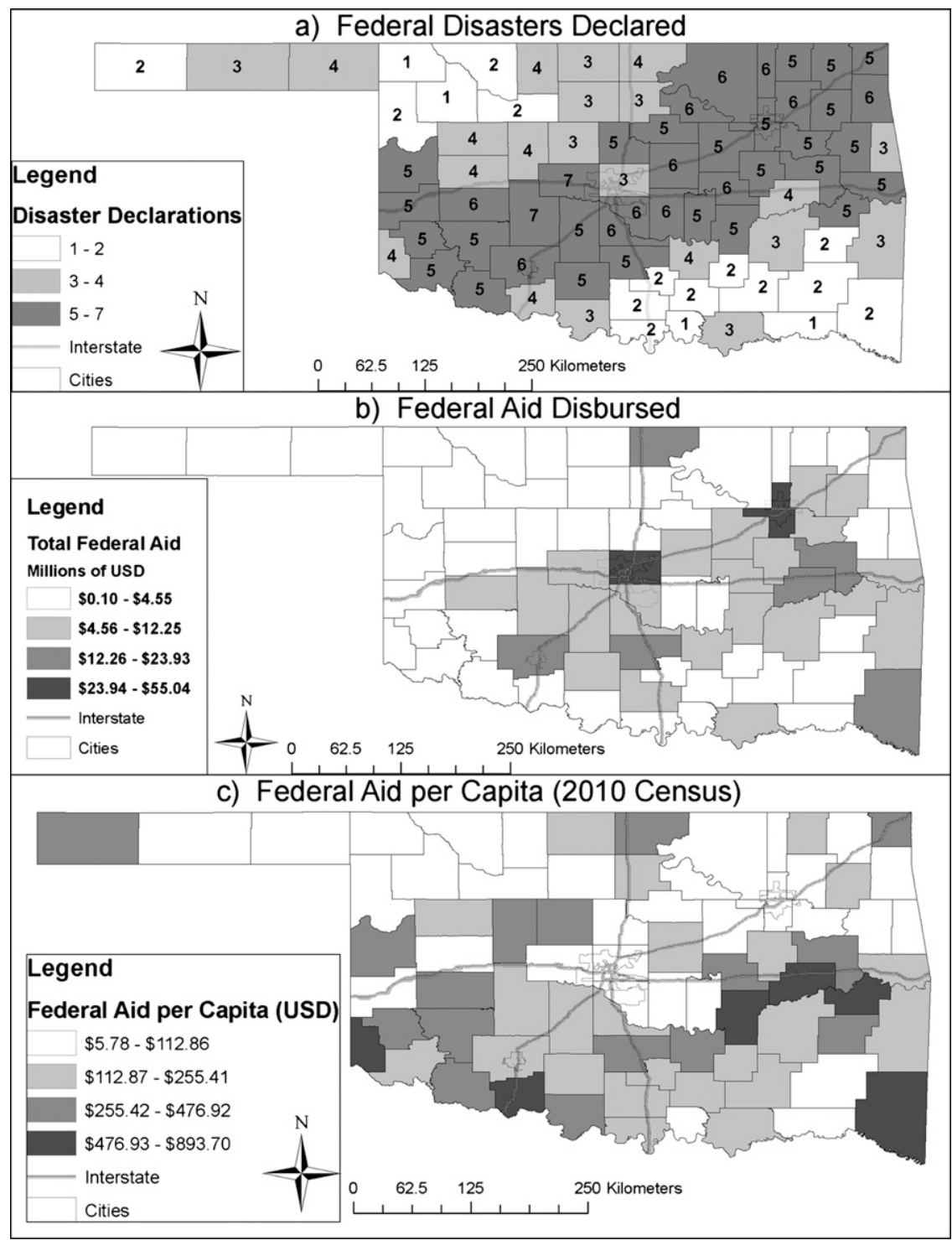

FIG. 1. (a) Major disaster declarations, (b) total FEMA monetary aid, and (c) FEMA aid per capita.

Oklahoma Panhandle, while the winter storm category was most frequently reported in north-central Oklahoma. Blizzard reports, although few, were primarily located in the western half of Oklahoma.

The patterns for blizzard and ice storm reports, arguably the most severe winter storm types, were spatially continuous throughout the study area. However, a reporting discontinuity between NWS CWAs was evident between the Amarillo CWA and the Norman CWA for the heavy snow and winter storm classifications. Another reporting discontinuity occurred, as winter weather reports were mostly confined to the Norman CWA and were virtually nonexistent in both the Tulsa and Amarillo CWAs. To account for this pattern of reporting, all winter events (from 2000 to 2010) were replotted without the winter weather reports to improve the overall consistency between NWS CWAs.

The temporal analysis of the winter events during the study period revealed that December and January received the most winter reports, while the overall frequency of the reports were winter storm (35\%), heavy snow $(26 \%)$, ice storm $(16 \%)$, winter weather $(20 \%)$, and blizzard $(3 \%)$. For particular classifications, ice storms were most frequently reported in December, while winter storm and heavy snow were most reported in December and January.

To better understand the frequency of these high-impact winter events, total winter reports (minus winter weather 


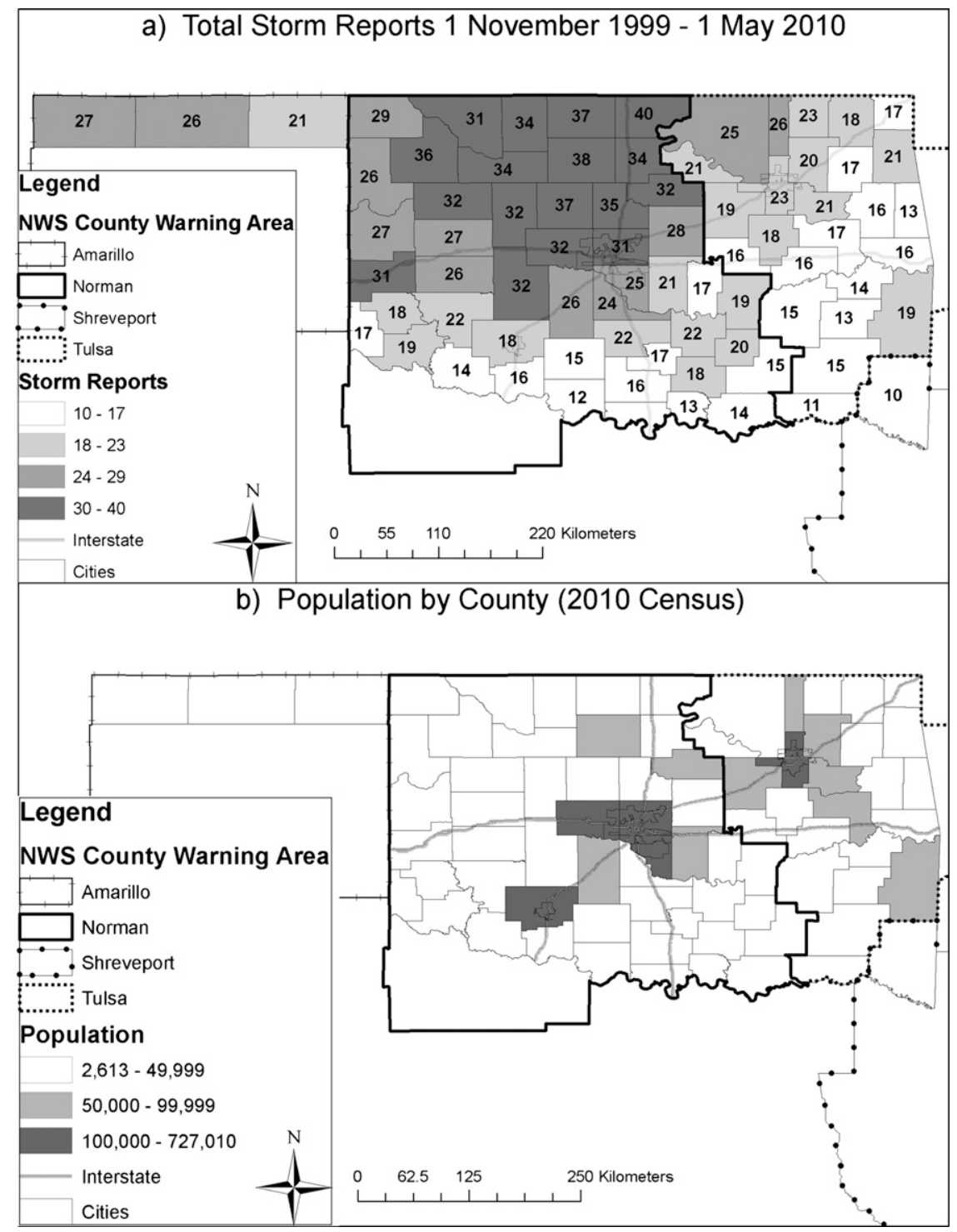

FIG. 2. (a) Total winter reports 1 Nov 1999-1 May 2010 and (b) population from 2010 census.

reports) were normalized with the number of major disasters declared (Fig. 4). The results yielded that southwest Oklahoma had the lowest ratio of storm reports to disasters (as low as 2.2 storm events per declared disaster), while northwest Oklahoma had the highest ratio of storms to disasters (as high as 22 storm events per declared disaster). Overall, the minimum number of storm reports to disasters was located in a southwest-northeast orientation across southwest, central, and northeast Oklahoma with much of southwest Oklahoma averaging three or fewer storm reports per declared disaster. Further, the ratio of ice storm reports during disaster declarations to total ice storm reports (Fig. 5) demonstrated that at least $50 \%$ of the ice storm events yielded a disaster for nearly $70 \%$ of all Oklahoma counties (more than $80 \%$ of the population). Thus, while not as frequent, when ice storm events occurred, they were usually associated with disaster-related conditions over widespread regions that impacted significant portions of the population. By comparison, the ratio involving the combined blizzard, heavy snow, and winter storm reports demonstrated that while such events often encompass large areas, generally less than $30 \%$ of the events would yield a disaster (Fig. 5).

When considering total winter reports, one of the most noticeable patterns was the discontinuity of reports between NWS CWAs. For example, the discontinuity was evident in the heavy snow and winter storm reports and was especially noticeable with the winter weather reports. In this case, the reporting discontinuity may be due to the preferences of the local NWS office. Given 
Storm Data Publication Summary

1 November 1999 - 1 May 2010

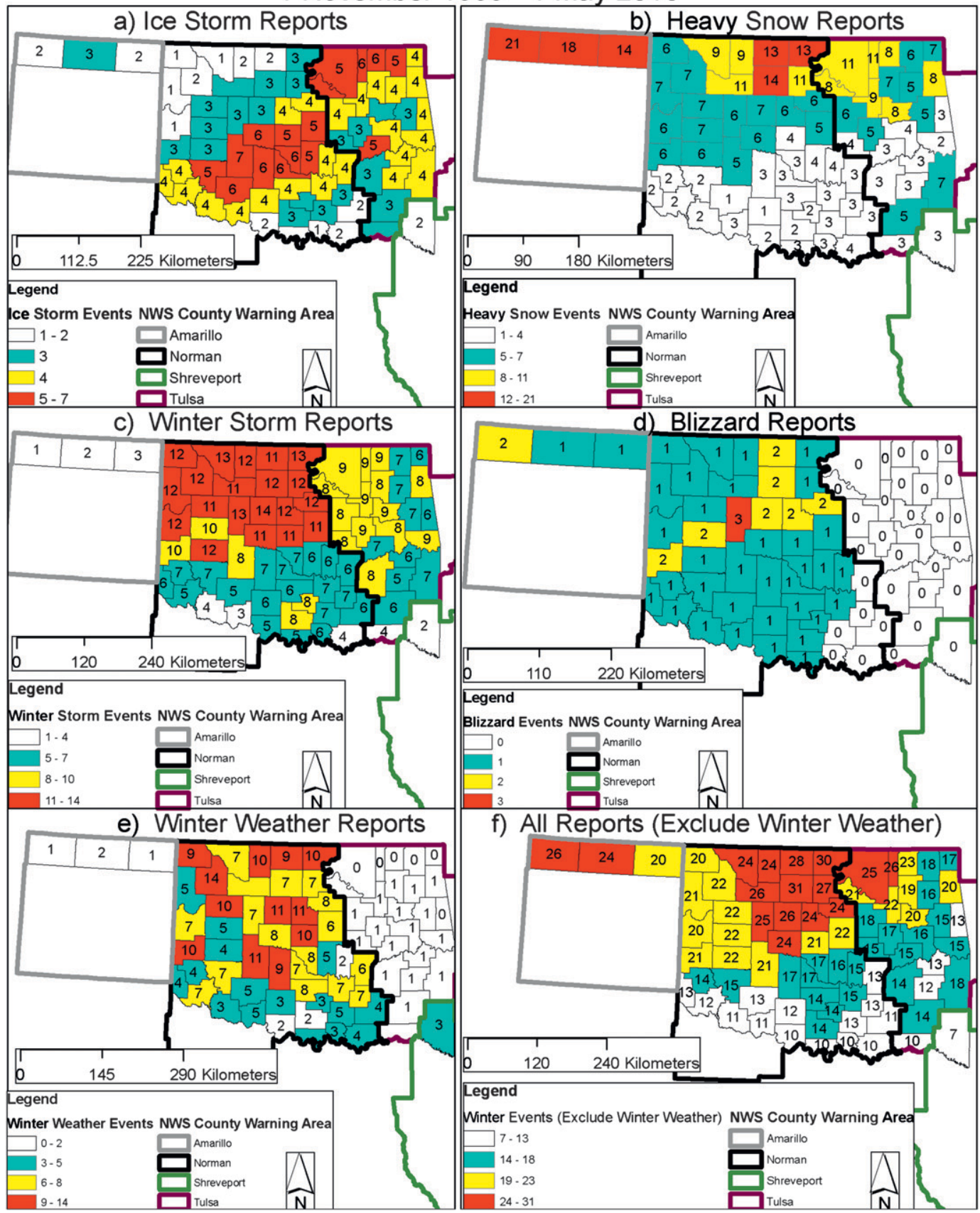

FIG. 3. Spatial distribution of storm types from 1 Nov 1999 to 1 May 2010: (a) ice storm, (b) heavy snow, (c) winter storm, (d) blizzard, (e) winter weather, and (f) all reports except winter weather.

the overlap of heavy snow and winter storm criteria, it is possible that the Norman NWS office prefers winter storm over heavy snow, especially because it is valid for multiple precipitation types: snow for heavy snow and either snow or sleet for winter storm. Another possible reason for the discontinuity of winter storm and heavy snow reports was based on the local, physical conditions. The more frequent heavy snow reports in the Oklahoma Panhandle may be due to a common storm track known as the Panhandle Hook, a type of cyclone that develops in the Oklahoma and Texas Panhandles and typically deposits heavy snow just to the north of its track as it 


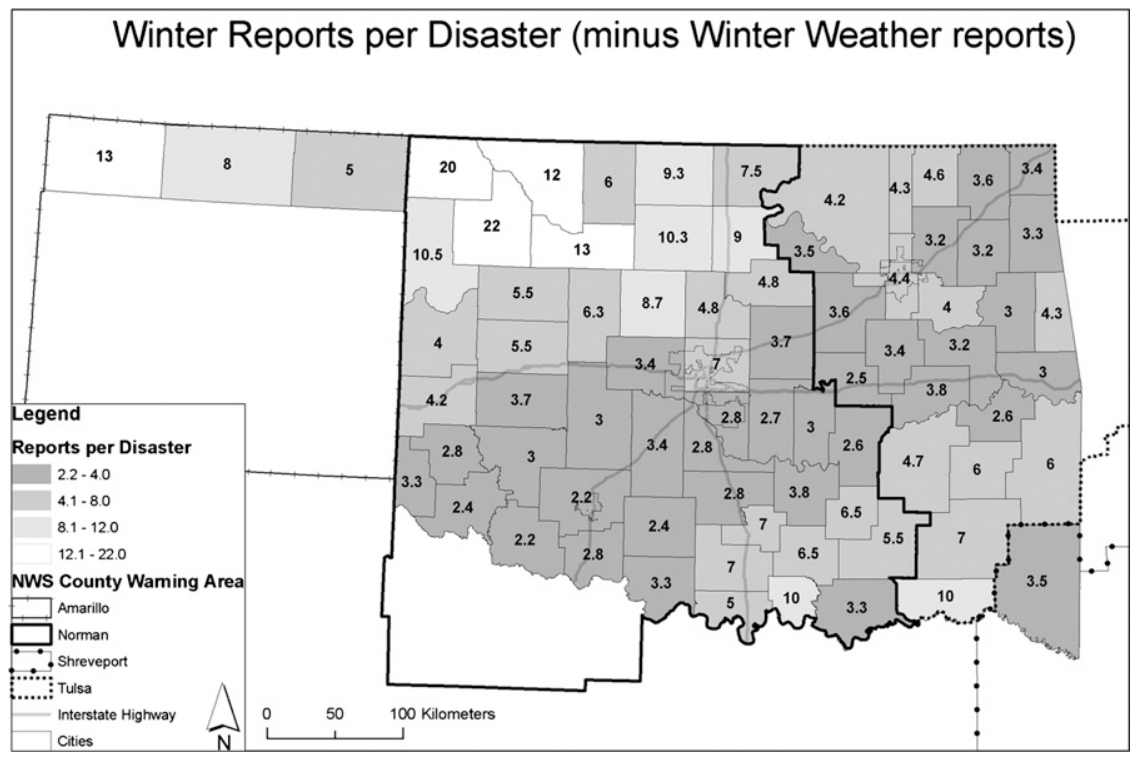

FIG. 4. Ratio of total winter reports (minus winter weather) to major disaster declarations.

moves northeast (NWS 2011a). The higher elevations in the Oklahoma Panhandle also contribute to more frequent snow events as opposed to mixed precipitation events.

The specific discontinuity of winter weather reports also suggests a difference in reporting preferences of the local NWS office. For this study, winter weather reports were virtually nonexistent in the Tulsa and Amarillo CWAs and were largely included within the Norman CWA. Winter weather reports typically reflect minor winter precipitation events, and local NWS forecast offices may not consistently report these low-impact events. Branick (1997) noticed reporting inconsistencies in a nationwide study of storm data and concluded statewide inconsistencies were possibly due to personnel at local NWS offices that have different standards of reporting.

\section{b. Climatological considerations}

Within broader climatological considerations, the study period was characterized by an anomalously greater number of significant winter-weather events. Changnon (2006) showed that for Oklahoma City (Oklahoma County in central Oklahoma), the 2-yr return period of a snow event was approximately $10 \mathrm{~cm}$ of snow. Over the study period (2000-10), Oklahoma County reported 15 heavy snow and winter storm reports, each with a minimum threshold of $10 \mathrm{~cm}$ of snowfall. While the winter storm category could be reported solely because of sleet, it is still reasonable that many, if not all, winter storm reports met the snowfall criteria of $10 \mathrm{~cm}$ of snowfall. As such, Oklahoma City experienced a 2-yr event more than once a year. Further, every county surrounding Oklahoma County also experienced at least 10 heavy snow and winter storm reports during the study period, which indicates that the local region exceeded climatological norms for significant snowfall (2000-10).

However, for all winter weather events, the results of this study noted that ice storms produce the greatest frequency of disaster conditions. During the study period, such events were most frequently reported in a southwestnortheast orientation across the central portion of the state. Such occurrences were critical given that $80 \%$ of Oklahoma's population resided in counties that recorded four or more ice storm reports and more than $40 \%$ of the population resided in counties that recorded five or more ice storm reports.

Climatologically, the entire South climate district of the United States (including Oklahoma and surrounding states) averages 5-6 catastrophic ( $>\$ 1$ million) ice storms per decade (Changnon 2003). Storm reports during all winter-related disaster declarations (2000-10) revealed that seven individual counties within Oklahoma experienced four or more catastrophic ice storm events during the study period. As such, some individual counties in Oklahoma experienced nearly as many catastrophic ice storms in the past decade as should impact a region that spans the entire South climate district of the United States (Changnon 2003). Further, Changnon (2003) noted that over the period spanning 1949-2000, the entire state of Oklahoma experienced 11 catastrophic ice storms or approximately 2 per decade. Conversely, more than half of all Oklahoma counties experienced between two and five catastrophic ice storms, measured by ice storm reports during disaster declarations, during the study period (2000-10). 


\section{a) Ice Storm Reports During Disasters to Total Ice Storm Reports}

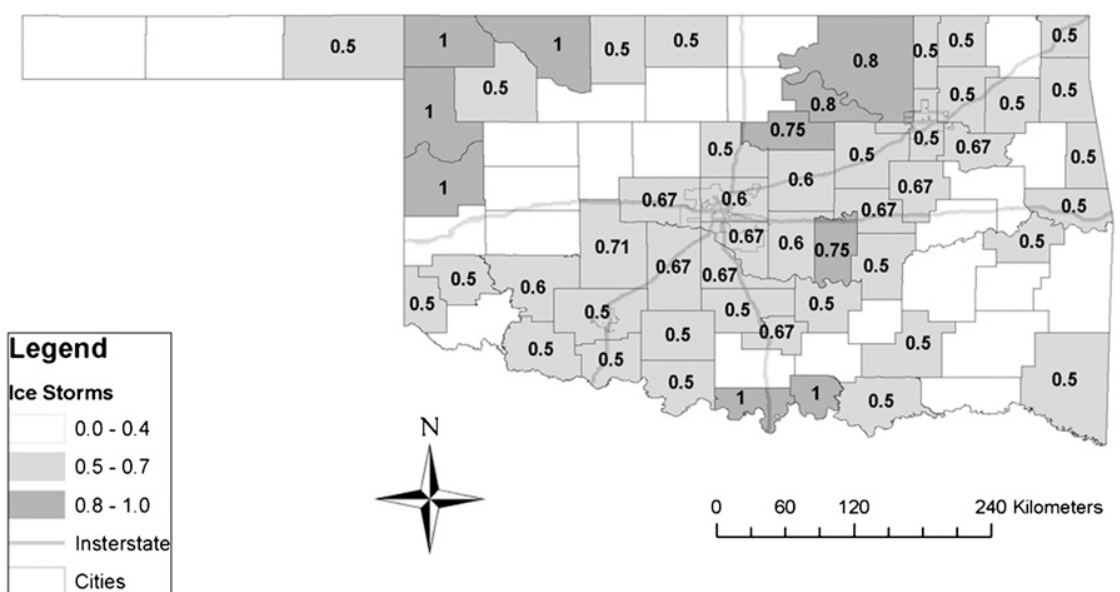

b) Blizzard, Heavy Snow, and Winter Storm Reports During Disasters to Total Blizzard, Heavy Snow, and Winter Storm Reports

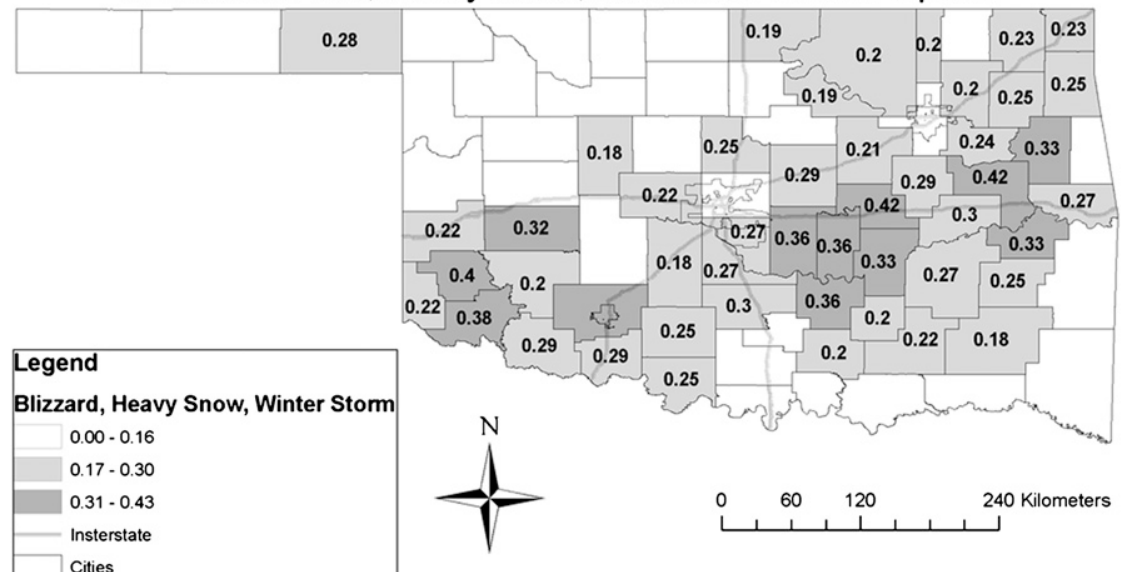

FIG. 5. Ratio of (a) ice storm reports during disasters to total ice storm reports and (b) blizzard, heavy snow, and winter storm reports during disasters to total blizzard, heavy snow, and winter storm reports from 1 Nov 1999 to 1 May 2010.

Similar to ice storm reports, blizzard reports were continuous across the state, further demonstrating that the highest impact storms were consistently reported between NWS forecast offices. Because blizzards include a wind criterion and climatologically stronger winds are located across the western portion of the state (OWPI 2011), such reports were generally isolated to the western half of Oklahoma. Schwartz and Schmidlin (2002) analyzed blizzards across the United States from 1959 to 2000 and noted that during that 40 -yr period, only northwest Oklahoma experienced any blizzards; approximately 10 blizzards were reported in the Oklahoma Panhandle and up to 3 in the northwest quarter of Oklahoma. However, from 2000 to 2010, the counties with the most blizzard reports were not located within the panhandle region but across central and southwest Oklahoma. Such results were significant given that the southwest quarter of Oklahoma, a region that climatologically experienced no blizzards within the Schwartz and Schmidlin (2002) study, had more blizzard reports within the study period (2000-10) than the entire $40 \mathrm{yr}$ previous (1959-2000). Further, when compared to the Schwartz and Schmidlin (2002) climatology, as many blizzard reports occurred during the study period (2000-10) over the northwest quarter of Oklahoma as were recorded over the previous 40 yr (1959-2000).

\section{c. FEMA analysis}

Although Oklahoma typically experiences fewer winter storms than other regions of the United States, the occurrence of high-impact storms, as defined by disaster declarations, were numerous during the study period. 
The areal coverage of these high-impact events was large: the average winter-related disaster encompassed approximately $45 \%$ of the 77 counties in Oklahoma, while the largest encompassed nearly $85 \%$ of all counties. Further, more than $60 \%$ of Oklahoma's population resided in counties that had at least five declarations during the study period and half of all Oklahoma counties were declared disasters at least 5 times. Within a larger perspective, from 1 November 1999 to 1 May 2010, such frequent local occurrences were greater than those for 43 entire states in the United States. The total aid (PA \& HM) allocated to the state of Oklahoma resulting from these disasters was approximately $\$ 800$ million (Table 2 ).

The purpose for gauging high-impact winter storms using disaster declarations (and allocated federal resources) is that it serves as a reliable baseline for estimating monetary damages and overall socioeconomic impact associated with these storms. While the total monetary disbursements to Oklahoma from FEMA totaled nearly $\$ 800$ million, the most populous counties, Oklahoma and Tulsa Counties, received the most monetary aid from the federal government when compared to other counties in the state. Whereas $49 \%$ of Oklahoma's population resides in five counties (each with a population of more than 100000 residents), these counties only accounted for $30 \%$ of federal disbursements due to disasters. As such, $70 \%$ of federal funds were disbursed to the remaining 72 , more rural, counties (which included $51 \%$ of the population) during the winter weather disasters. Thus, when associated disbursements were normalized to population, the highest cost per capita occurred in rural counties outside of the main population centers. Statistically, counties in the upper 50th percentile of disbursement per county ( $\geq \$ 142$ per capita) accounted for $25 \%$ of the population and counties that had higher than the 75 th percentile ( $\geq \$ 284$ per capita) accounted for only $10 \%$ of the population.

The allocation of federal resources in this manner demonstrates that although the most populous counties received the greatest sum total of funds, the rural locales were most impacted by the high-impact winter storms and required more aid per given population base due to prolonged impact on local infrastructure. The results are consistent with Call (2010), who noted that rural regions are more likely to suffer from prolonged power outages because utilities initially focus on regions with higher numbers of customers. In addition, rural counties are less likely to have the resources (personnel and updated technology) of more populated counties. Thus, when a widespread, high-impact winter weather event occurs, rural areas require more external assistance than the local tax base can accommodate. As these rural populations grow and communities develop, this will further increase their vulnerability to high-impact storms and potentially increase the costs that the local tax base must be able to accommodate.

For the study period, the highest cost per capita of federal funds due to disasters is located across the southern half of Oklahoma, particularly southwest Oklahoma, which was also the region of some of the lowest storm report per disaster ratios. As such, southwest Oklahoma, which was largely rural, was particularly vulnerable to the frequent, high-impact winter events that occurred during the period and relied on increased external sources to assist with recovery.

\section{Conclusions}

Oklahoma led the nation with nine winter-related disaster declarations during the focus period of this study (1 November 1999-1 May 2010), which accounted for nearly $\$ 800$ million (U.S. dollars) in total aid from the U.S. federal government. When compared with past climatological analyses, the number and intensity of the high-impact winter weather events was anomalously large across most of Oklahoma and particularly over southern and central portions of the state. For example, central Oklahoma experienced, on average, a 2-yr snow event (Changnon 2006) nearly every year, while southwest and central Oklahoma experienced as many or more blizzards during the study period than over the previous 40-yr period from 1959 to 2000 (Schwartz and Schmidlin 2002). In addition, at least half of all Oklahoma counties reached or exceeded the 10-yr statewide, climatological average of catastrophic ice storms (Changnon 2003). Such ice storm events were particularly devastating across much of southern, central, and northeastern Oklahoma, and the results of this study demonstrated that statewide approximately $50 \%$ of all ice storm reports occurred during disaster declaration periods. Because the number of ice storm events was anomalously large and encompassed large spatial areas during each event, the impacts frequently occurred in less prepared regions.

The devastating socioeconomic impacts of these winter weather disasters was, in part, revealed by the federal aid distributed to regions across the state. The spatial distribution of the aid revealed that, while the two most populous counties received the most monetary aid, overall the rural counties 1) received the majority of federal aid from the disaster events and 2) yielded greater per capita cost than the more populated counties. Thus, rural regions, with fewer resources at their disposal, were more impacted by the high-impact winter weather events and required more assistance from outside resources. 
Acknowledgments. This project was funded by the Oklahoma University Transportation Center Project Number OTCREOS9.1-02. In addition, David Andra, Science and Operations officer at the Norman NWS office, was helpful in obtaining storm type definitions for forecast offices throughout Oklahoma. The authors also acknowledge and thank the anonymous reviewers, whose input and constructive comments during the peer review process greatly improved and enhanced this manuscript.

\section{REFERENCES}

Branick, M. L., 1997: A climatology of significant winter-type weather events in the contiguous United States, 1982-94. Wea. Forecasting, 12, 193-207.

— , cited 2011: Monthly and geographic distribution of heavy snow events in Oklahoma, 1951-2001. National Weather Service Tech. Attachment SR SSD 2002-09, 4/2002. [Available online at http://www.srh.noaa.gov/topics/attach/html/ssd0209.htm.]

Call, D. A., 2010: Changes in ice storm impacts over time: 18862000. Wea. Climate Soc., 2, 23-35.

Changnon, S. A., 2003: Characteristics of ice storms in the United States. J. Appl. Meteor., 42, 630-639.

- 2006: Frequency distributions of heavy snowfall from snowstorms in the United States. J. Hydrol. Eng., 11, 427.

_- 2007: Catastrophic winter storms: An escalating problem. Climatic Change, 84, 131-139.

— of freezing rain in the contiguous United States: 1948-2000. J. Appl. Meteor., 42, 1302-1315.

- D. Changnon, and T. R. Karl, 2006: Temporal and spatial characteristics of snowstorms in the contiguous United States. J. Appl. Meteor. Climatol., 45, 1141-1155.

FEMA, cited 2011a: FEMA disaster declaration summary. [Available online at http://explore.data.gov/Other/FEMA-DisasterDeclarations-Summary/uihf-be6u.]

— http://www.fema.gov/femaNews/disasterSearch.do?action=Reset.]

— [Available online at http://explore.data.gov/Other/FEMAHazard-Mitigation-Program-Summary/wsf8-txi9.]
_ , cited 2011d: FEMA public assistance funded projects summary. [Available online at http://explore.data.gov/Other/FEMAPublic-Assistance-Funded-Projects-Summary/btjd-2xvr.]

_ cited 2011e: Presidential disaster declarations: December 24, 1964 to January 1, 2010. [Available online at http://www. gismaps.fema.gov/historical.pdf.]

— 2000 to January 2, 2010. [Available online at http://www. gismaps.fema.gov/recent.pdf.]

_ [Available online at http://www.fema.gov/hazard/dproc.shtm.]

Jones, K., R. Thorkildson, and N. Lott, 2002: The development of a U.S. climatology of extreme ice loads. National Climatic Data Center Tech. Rep. 2002-01, 23 pp. [Available online at http://purl.access.gpo.gov/GPO/LPS105567.]

NOAA, cited 2011: Storm Data reference notes. [Available online at http://www.ncdc.noaa.gov/oa/climate/sd/referencenotes.pdf.]

NWS, cited 2011a: National Weather Service glossary. [Available online at http://www.weather.gov/glossary/.]

_ 2011b: WFO winter weather products specifications. National Weather Service Instruction NWSI 10-513, 41 pp. [Available online at http://www.weather.gov/directives/sym/ pd01005013curr.pdf.]

Orszag, P. R., 2009: Memorandum for the heads of executive departments and agencies: Open government directive. Executive Office of the President, M-10-06, 11 pp. [Available online at http://www.whitehouse.gov/open/documents/open-governmentdirective.]

OWPI, cited 2011: Oklahoma wind resource map: Estimated wind speeds at 50 meters. [Available online at http://www.ocgi. okstate.edu/owpi/OKWindInfo/OWPI_documents/OK_Wind_ Resource_Map.pdf.]

Rauber, R. M., L. S. Olthoff, M. K. Ramamurthy, D. Miller, and K. E. Kunkel, 2001: A synoptic weather pattern and soundingbased climatology of freezing precipitation in the United States east of the Rocky Mountains. J. Appl. Meteor., 40, 1724-1747.

Salkowe, R. S., and J. Chakraborty, 2009: Federal disaster relief in the U.S.: The role of political partisanship and preference in presidential disaster declarations and turndowns. J. Homeland Secur. Emerg. Manage., 6, doi:10.2202/1547-7355.1562.

Schwartz, R. M., and T. W. Schmidlin, 2002: Climatology of blizzards in the conterminous United States, 1959-2000. J. Climate, 15, 1765-1772.

Sylves, R., and Z. I. Búzás, 2007: Presidential disaster declaration decisions, 1953-2003: What influences odds of approval? State Local Gov. Rev., 39, 3-15. 